\title{
DIAGNOSTIC VALUE OF TUMOUR MARKERS CA-125 AND CEA IN THE DIAGNOSTICS OF MALIGNANT PLEURAL FLUIDS
}

\author{
Dace Žentinaa $^{1,} 2$ \#, Inga Stuḳēna ${ }^{1,2}$, Sarma Grīnberga ${ }^{3}$, Alvils Krams ${ }^{1,} 4$, \\ and Aivars Lejnieks ${ }^{1,2}$

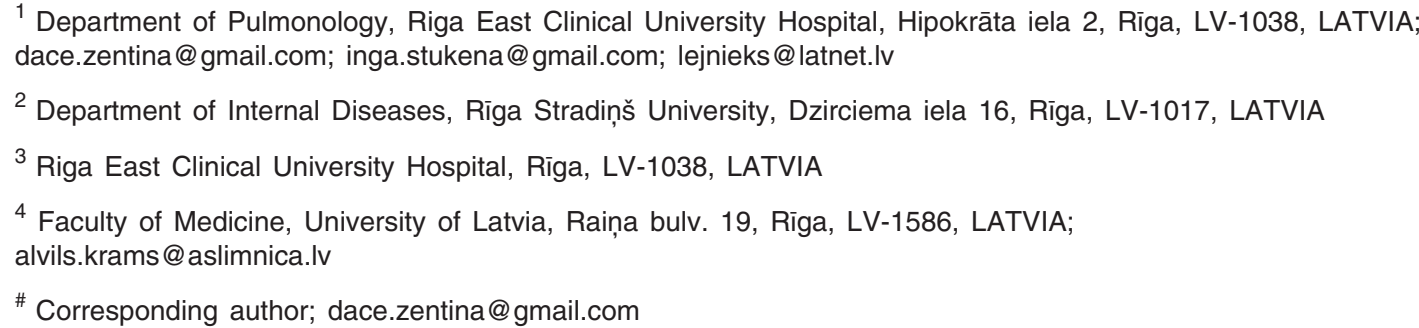

Contributed by Aivars Lejnieks

The significance of carbohydrate (cancer) antigen 125 (Ca-125) and carcinoembryonic antigen (CEA) tumour markers levels in differential diagnostics of malignant and benign pleural effusion was studied. Within this prospective study, 121 patients with fluids of various aetiology in the pleural cavity were analysed. Malignant pleural effusion was detected in 55 patients, parapneumonic effusion in 28 patients, transudative effusion of cardiac origin in 31 patients, pancreatitis in one patient and tuberculous pleurisy in five patients. The highest accuracy in diagnosis of malignancy was observed for Ca-125 and CEA levels in the pleural fluid: $75.2 \%$ at cut-off value $\geq 1452$ $U / \mathrm{mL}$ and $76.9 \%$ at cut-off value $\geq 6.58 \mathrm{ng} / \mathrm{mL}$, respectively. We conclude that the level of tumour markers in pleural fluid has additional diagnostic significance in the differential diagnosis of malignant and benign pleural effusions.

Key words: pleural fluid, malignant effusion, tumour markers, CA-125, CEA.

\section{INTRODUCTION}

Pleural effusion - pathological content in the pleural cavity - is a comparatively frequent complication of various diseases. No data of large-scale epidemiological trials are available; however, the number of pleural pathology patients is estimated at 3000 cases per million population a year (Hooper, 2010). Malignancy is one of the most frequent causes of pleural fluids (Rodriguez-Pandero, 2003). Upon examination of the pleural puncture fluid the presence of malignant effusion is considered to be proven if malignant cells are detected in cytological examination; however, the mean sensitivity of cytological examination is approximately $60 \%$ and depends on sample preparation, the experience of the cytologist and on tumour type (Hooper, 2010). The most informative method of diagnosing malignant pleural effusion is diagnostic thoracoscopy, which enables collection of pathologically altered tissue samples under visual control and proving the diagnosis histological; however, in practice faster, cheaper, and less invasive procedures are often required for the specification of the patient's diagnosis. Thus, new markers that are sufficiently sensitive to prove the probability of malignancy are being sought.
Cancer antigen Ca-125 is a high molecular mass protein, which is produced by epithelial ovary cancers and mesothelial cells. Ca-125 is most frequently used to monitor the results of ovarian cancer therapy; however, Ca-125 can be elevated in the event of both malignant and benign pathologies, probably because of the involvement of serous membranes and the irritation of mesothelial cells (Miralles, 2003; How et al., 2006). The mechanism of this process is not fully known yet. Levels of Ca-125 are most frequently estimated in blood serum, while the levels in serous cavity fluids tend to be more informative (Korczynski, 2009).

CEA (carcinoembryonic antigen) is a glycoprotein involved in cell adhesion, which is produced during the embryonic development. The synthesis of CEA ceases upon birth; however, elevated levels of CEA are observed detected in patients with colorectal, pancreatic, lung and breast cancer, in smokers, cirrhosis patients, as well as in certain other cases. Although CEA is not a specific indicator, the level of CEA can increase 4-8 times before the clinical symptoms caused by a tumour develop (Nicholson et al., 2014). 
A hypothesis can be brought forward: tumour markers Ca125 and CEA in pleural effusion are diagnostic markers of malignancy.

The goals of the research were:

1. To determine the Ca-125 and CEA levels in serum and pleural effusion, as well as Ca-125 and CEA effusion/serum ratios in patients with pleural effusion;

2. To compare the Ca-125 and CEA levels in patients with malignant pleural effusion and those with pleural effusions of different aetiology;

3. To establish diagnostic validity of tumour markers Ca125 and CEA in differential diagnosis of pleural effusion.

\section{MATERIALS AND METHODS}

The research protocol was confirmed by the Ethics Committee of Rìga Stradiņš University. An approved informed consent form was signed from all subjects.

In the period from 1 August 2008 to 22 April 2013, 121 patients consecutively admitted at the $2^{\text {nd }}$ Pulmonology Department, Gailezers Clinic of Rīga East Clinical University Hospital, with radiological and ultrasound findings of fluid in the pleural cavity, were included in the study. All patients included in the study were subject to pleural puncture in accordance with clinical indications. Light's criteria (Light et $a l ., 1972$ ) for the differentiation between exudative effusion and transudative effusion were determined and clinical and cytological analysis of pleural fluid sample was performed. Patients in whom clinical analysis revealed the count of monomorphonuclear cells to be $>95 \%$, were subject to blind pleural biopsy, which involves collection of core biopsy samples through the chest wall for histological examination. Venous blood samples and pleural effusion samples were collected from each patient in an EDTA vacutainer, centrifuged for 10 minutes at $3000 \mathrm{rpm}$ to obtain plasma samples and stored at $-80{ }^{\circ} \mathrm{C}$ until assayed. Ca-125 and CEA were measured with ELISA using an Abbott Architect device according to the manfacturer's protocol. In order to draw conclusions on the clinical significance of the markers, the sensitivity and specificity of both marker levels in serum and punctate as well as the proportion of markers in punctate/serum were calculated. Receiver operating characteristic (ROC) curves and area under the curve (AUC) analysis were estimated. Pleural fluid was considered to be malignant if malignant cells were found in the pleural fluid, or if the patient had had a previously confirmed malignant disease and no other cause for the presence of pleural fluid was found (Sahn, 1997). Diagnosis of tuberculous pleurisy was confirmed by finding specific changes - tuberculous granulomas during the histological examination of the pleural fluid. Parapneumonic pleurisy or pleural empyema was diagnosed in patients with acute onset of the disease, febrile temperature, chest pain, infiltrates in chest X-Ray examination or computed tomography scans and positive bacterial culture in pleural cavity, in case other causes were ex- cluded. Transudative effusion was diagnosed in cardiac failure patients based on signs of cardiac failure (peripheral oedema, history of known cardiac disease, echocardiogramm signs of cardiac failure or venous congestion in the chest X-ray). Elevated lipase level in the pleural fluid was used to diagnose pleurisy associated with pancreatitis.

Statistical analysis. Microsoft Excel and online software for the Chi-squared $\chi^{2}$ test with calculation of significant differences (Preacher, 2001) were used for data processing, as well as teh VassarStats online computer programme for calculation of test sensitivity and specificity (Lowry, 1998-2012). In accordance with generally accepted principles in medical statistics, a $p$ value of 0.05 was considered to be the statistical significance threshold.

The arithmetic mean and standard deviation was used for the description of quantitative variables; however, if the data distribution did not conform to the norm, we used median and quartiles $\mathrm{Q}_{1}$ and $\mathrm{Q}_{3}$, as well as the range (minimum and maximum values). The conformity of data to the norm was checked using a Kolmogorov-Smirnov test and histograms.

The Chi-squared $\chi^{2}$ test was used for the comparison of categorical variables in different groups.

\section{RESULTS}

The presence of fluid in the pleural cavity was found in 121 patients from 30 to 90 years of age; $62(57 \%)$ of the patients were male. Malignant pleural effusion was detected in 55 patients, parapneumonic effusion in 28 patients, transudative effusion of cardiac origin in 31 patients, pancreatitis in 1 patient, and tuberculous pleurisy in 5 patients (Table 1). In the group of malignant pleurisies, 11 patients had breast cancer, 11 patients ovarian cancer, 19 patients lung cancer, 2 patients renal cancer, 2 patients cervical cancer, 2 gastric cancer, 1 patient pancreatic cancer, 1 sarcoma, 1 pleural mesothelioma, and unknown primary cancer in 5 patients (Table 2). The sensitivity of cytological examination was $71 \%$, specifity - $100 \%$.

In order to determine whether statistically significant differences between Ca-125 and CEA in the pleural fluid of different aetiology exist, the groups of parapneumonic pleu-

Table 1

BASELINE CHARACTERISTICS OF PATIENTS WITH PLEURAL EFFUSION, $\mathrm{n}=121$

\begin{tabular}{llc}
\hline & Indicator & $\mathrm{n}(\%)$ or mean \pm SD (range) \\
\hline Age & Years & $70($ range 22-90) \\
Gender & Male & $62(51 \%)$ \\
& Female & $59(49 \%)$ \\
Diagnosis & Cardiac transudate & $31(25.6 \%)$ \\
& Parapneumonic effusions & $28(23.1 \%)$ \\
& Malignant effusion & $55(45.5 \%)$ \\
& Tuberculous effusion & $5(4.1 \%)$ \\
& Pancreatitis & $1(0.8 \%)$
\end{tabular}


Table 2

LOCALISATION OF PRIMARY CANCER IN PATIENTS WITH MALIGNANT EFFUSIONS, $\mathrm{n}=55$

\begin{tabular}{l|l}
\hline \multicolumn{1}{c|}{ Primary localization } & $\mathrm{n}$ \\
\hline Lung cancer & 19 \\
Breast cancer & 11 \\
Ovarian cancer & 11 \\
Kidney cancer & 2 \\
Cervical cancer & 2 \\
Stomach cancer & 2 \\
Pancreas cancer & 1 \\
Uterine leiomyosarcoma & 1 \\
Pleural mesothelioma & 1 \\
Unknown primary cancer & 5
\end{tabular}

risy, malignant pleural effusion and transudative effusion were subject to further analysis. Median serum and pleural fluid levels of Ca-125 and CEA were determined in all three groups (Table 3). Tuberculous pleurisy and pleurisy due to pancreatitis were not included in further analysis due to the small number of patients.

In almost all cases (except Ca-125 effusion/serum ratio) the highest accuracy was found when the cut-off or differentiation of malignant effusion was set based on the $3^{\text {rd }}$ quartile rather than $1^{\text {st }}$ or $2^{\text {nd }}$ (Table 4). The accuracy ranged from $64 \%$ to $77 \%$ for CEA marker and from $58 \%$ to $75 \%$ for Ca-125. Similarly, the sensitivity was also highest for cut-offs based on the $75^{\text {th }}$ percentile, while the specificity was best at the $25^{\text {th }}$ percentile. Thus, the highest accuracy was found for Ca-125 effusion of $\geq 1452 \mathrm{U} / \mathrm{ml}(75.2 \%)$ and for CEA effusion of $\geq 6.58 \mathrm{mg} / \mathrm{ml}$ (76.9\%). Area under curves was also highest in CA-125 in pleural effusion and CEA in pleural effusion, 0.793 and 0.761 , respectively (Table 5, Figure 1).

\section{DISCUSSION}

In order to establish the probable significance of the Ca-125 tumour marker in differential diagnosis of pleurisy, 121 patients with fluid in the pleural cavity were examined.

It was found that higher accuracy and sensitivity either for Ca-125 or CEA levels were found when the $75^{\text {th }}$ percentile was used as the cut-off value, while the highest specificity was found using the $25^{\text {th }}$ percentile as the cut-off value. The highest positive predictive value was established for $\mathrm{Ca}-125$ and CEA concentration in the pleural fluid, in contrast to the concentration of these markers in the serum or ratios of fluid/serum concentration. Thus, concentrations in pleural fluid allow to make conclusions on its local production in both impaired mesothelial cells (Ca-125) and malignant cells. A high pleural puncture fluid/serum ratio of Ca-125 for malignant effusion in comparison with the fluid of other origin in the pleural cavity can indicate limited systemic diffusion.

Ma et al. (2013) retrospectively determined the level of Ca-125 in blood serum in 2115 patients with chronic cardiac failure aged over 85 and found that the $\mathrm{Ca}-125$ level in blood serum was significantly elevated in patients with fluid in the pleural cavity and peripheral oedema. DurakNalbantic et al. (2013) measured Ca-125 in the serum of 76 patients with cardiac failure and came to the same conclusion: serum Ca-125 level was higher in patients with fluid in the pleural and pericardial cavities. Turk et al. (2003), compared cardiac failure patients with and without transudate in pleural cavity and healthy volunteers, and also found that the Ca-125 level was significantly higher in patients with cardiac failure and transudative effusion in pleural cavity. In our study we did not find a signicant difference in Ca-125 level in patients with cardiac failure and transudative effusion in the pleural cavity and in patients with malignant pleural effusion $(p<0.139)$; however, the difference

Table 3

MEDIAN SERUM AND PLEURAL FLUID LEVELS OF CA-125 AND CEA IN PATIENTS WITH TRANSUDATIVE EFFUSION, MALIGNANT EFFUSION AND PARAPNEUMONIC PLEURISY

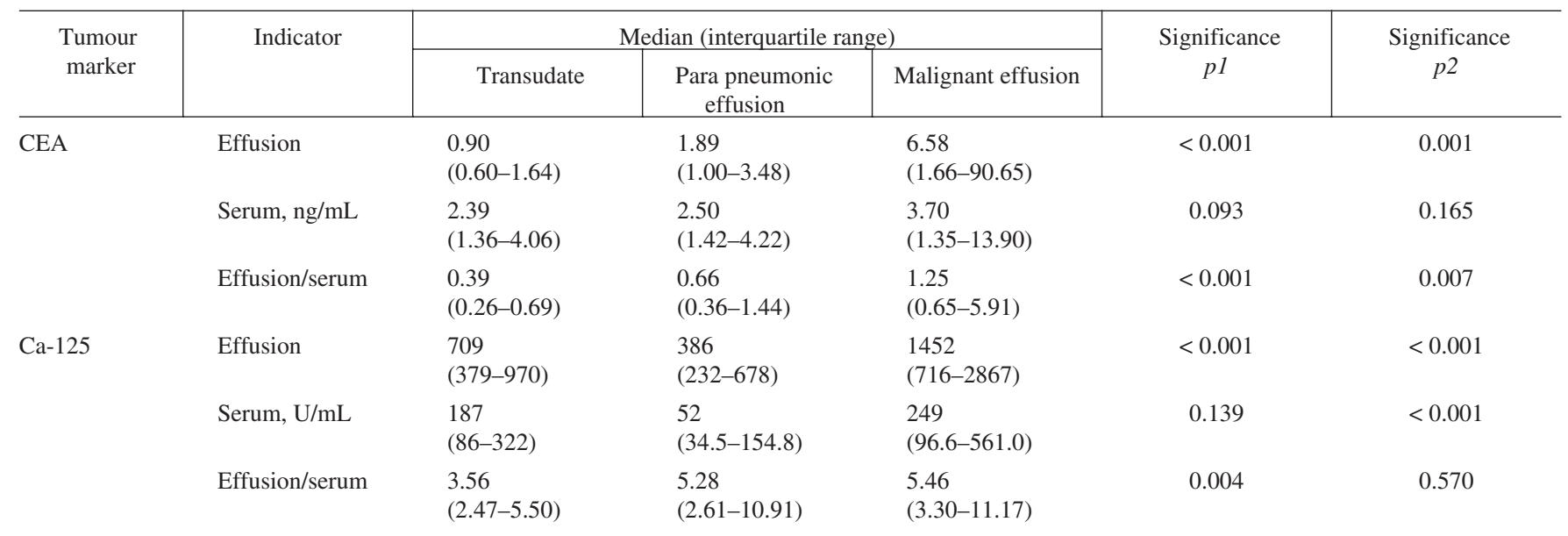

pl, significance between transudative effusion vs. malignant effusion

$p 2$, significance between parapneumonic effusion vs. malignant effusion 
CA-125 (U/ML) AND CEA (NG/ML) AS DIAGNOSTIC INDICATORS IN THE DIFFERENTIATION OF MALIGNANT EFFUSION

\begin{tabular}{c|c|c|c|c|c}
\hline $\begin{array}{c}\text { Tumour } \\
\text { marker }\end{array}$ & Indicator & $\begin{array}{c}\text { Cut-off } \\
\text { value }\end{array}$ & Sensitivity & Specificity & Accuracy \\
\hline CEA & Effusion & $\geq 0.76$ & $81.8 \%$ & $36.4 \%$ & $57.0 \%$ \\
& & $\geq 1.99$ & $74.5 \%$ & $65.2 \%$ & $69.4 \%$ \\
& & $\geq 6.58$ & $58.2 \%$ & $92.4 \%$ & $76.9 \%$ \\
& Serum & $\geq 1.40$ & $70.9 \%$ & $31.8 \%$ & $49.6 \%$ \\
& & $\geq 2.77$ & $60.0 \%$ & $56.1 \%$ & $57.9 \%$ \\
& & $\geq 4.68$ & $41.8 \%$ & $87.9 \%$ & $66.9 \%$ \\
& Effusion/ & $\geq 0.40$ & $90.9 \%$ & $28.8 \%$ & $57.0 \%$ \\
& serum & $\geq 0.71$ & $72.7 \%$ & $56.1 \%$ & $63.6 \%$ \\
& & $\geq 1.58$ & $49.1 \%$ & $84.8 \%$ & $68.6 \%$ \\
\hline Ca-125 & Effusion & $\geq 347$ & $85.5 \%$ & $51.5 \%$ & $66.9 \%$ \\
& & $\geq 768$ & $70.9 \%$ & $72.7 \%$ & $71.9 \%$ \\
& & $\geq 1452$ & $54.5 \%$ & $92.4 \%$ & $75.2 \%$ \\
& & $\geq 56$ & $83.6 \%$ & $30.3 \%$ & $54.5 \%$ \\
& Serum & $\geq 167$ & $67.3 \%$ & $63.6 \%$ & $65.3 \%$ \\
& & $\geq 344$ & $41.8 \%$ & $86.4 \%$ & $66.1 \%$ \\
& & $80.5 \%$ & $34.8 \%$ & $55.4 \%$ \\
& & 69.56 & $57.6 \%$ & $58.7 \%$ \\
& & & $81.8 \%$ & $57.9 \%$ \\
& & & &
\end{tabular}

in levels in the pleural fluid did significantly differ $(p<$ $0.001)$.

Choi et al. (2013) determined Ca-125 levels in pleural puncture fluid of 326 patients and afterwards retrospectively
AREA UNDER THE CURVE FOR CEA LEVEL IN EFFUSION, SERUM, AND EFFUSION/SERUM RATIO AND FOR CA-125 LEVEL IN EFFUSION, SERUM AND EFFUSION/SERUM RATIO

\begin{tabular}{|c|c|c|c|c|c|c|}
\hline \multirow[t]{2}{*}{$\begin{array}{l}\text { Tumour } \\
\text { marker }\end{array}$} & \multirow[t]{2}{*}{ Variables } & \multirow{2}{*}{$\begin{array}{c}\text { Area un- } \\
\text { der the } \\
\text { curve }\end{array}$} & \multirow[t]{2}{*}{$\begin{array}{c}\text { Standart } \\
\text { error }\end{array}$} & \multirow[t]{2}{*}{$p$ value } & \multicolumn{2}{|c|}{$\begin{array}{c}95 \% \text { Conffidence } \\
\text { Interval }\end{array}$} \\
\hline & & & & & $\begin{array}{l}\text { lower } \\
\text { bound }\end{array}$ & $\begin{array}{l}\text { upper } \\
\text { bound }\end{array}$ \\
\hline \multirow[t]{3}{*}{ CEA } & Effusion & 0.761 & 0.047 & 0.001 & 0.668 & 0.854 \\
\hline & Serum & 0.609 & 0.054 & 0.004 & 0.503 & 0.714 \\
\hline & $\begin{array}{l}\text { Effusion/ } \\
\text { serum }\end{array}$ & 0.741 & 0.046 & 0.001 & 0.651 & 0.832 \\
\hline \multirow[t]{3}{*}{ Ca-125 } & Effusion & 0.793 & 0.042 & 0.001 & 0.710 & 0.876 \\
\hline & Serum & 0.705 & 0.048 & 0.001 & 0.611 & 0.799 \\
\hline & $\begin{array}{l}\text { Effusion/ } \\
\text { serum }\end{array}$ & 0.625 & 0.051 & 0.018 & 0.524 & 0.726 \\
\hline
\end{tabular}

analysed its level in patients with various aetiology of the pleural fluid. It was concluded that significant elevation of Ca-125 occurred in patients with pleural fluid of malignant origin (more than $1 / 3$ of the patients had Ca-125 levels of $>600 \mathrm{U} / \mathrm{ml})$, but the difference was statistically insignificant in patients with transudative effusion and fluid of benign aetiology in the pleural cavity. No significant differences in Ca-125 levels were detected for patients with cancer of different localisation as well, which leads to the conclusion that the impairment of mesothelial cells does not depend on the type of cancer. According to our calculations, the medial level of Ca-125 in malignant pleural effusion was 1452 $\mathrm{U} / \mathrm{ml}$ and the difference in its level in the event of malignant effusions from either transudative effusion or parapneu-

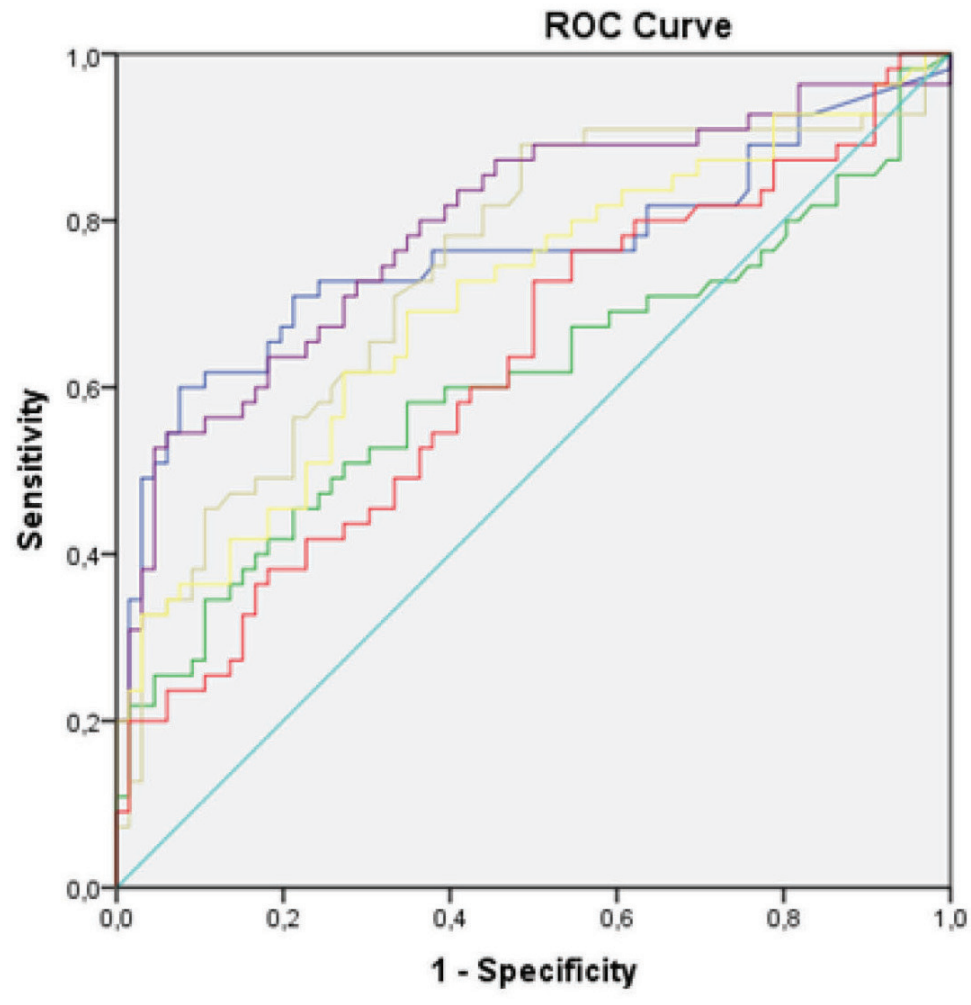

Diagonal segments are produced by ties.

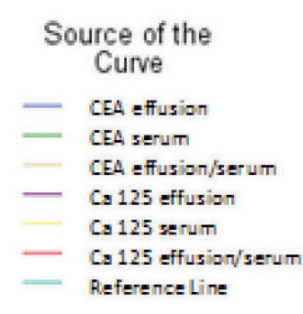

Fig. 1. Receiver operating characteristic (ROC) curves for CEA level in effusion, serum, effusion/serum ratio and for $\mathrm{Ca}-125$ level in effusion, serum, effusion/serum ratio. 
monic pleurisy cases was statistically significant $(p<$ $0.001)$.

Kalantri et al. (2007) analysed non-specific elevation of Ca-125 in 38 patients with pleural fluid and 46 patients with ascites (including either exudative effusion or transudative effusion). It was found that the elevation of Ca-125 was statistically significant in patients with ascites of any aetiology, which allowed to conclude that mesothelial cells of the abdominal cavity have a higher capacity for producing this substance.

Bielsa et al. (2009) determined various tumour markers, including CEA and Ca-125, in 224 patients with confirmed malignant pleural effusion in the pleural fluid. They found that a level of Ca-125 above $1000 \mathrm{U} / \mathrm{ml}$ in combination with fragments of cytokeratin 19 - CYFRA $21-1$ of $>100 \mathrm{ng} / \mathrm{ml}$ was significantly associated with lower survival (Bielsa et al., 2009).

Xu et al. (2015) determined the level of CEA in 60 malignant and 58 benign pleural fluids and established that in 54 patients with malignant pleural effusion the level of CEA was $>5.5 \mathrm{ng} / \mathrm{ml}$ and at this cut-off value the combination of CEA with tumour marker Type II membran protein RCAS yielded sensitivity of 98.3 and specificity of $91.4 \%$ (Xu et al., 2015); according to our data, at a cut-off value of 6.58 $\mathrm{ng} / \mathrm{ml}$ the sensitivity of CEA was $58.2 \%$ and specificity $92.4 \%$.

Son et al. (2015) analysed 47 benign and 52 malignant pleural effusions and compared the diagnostic values of tumour markers CD66c, CEA, Ca 19-9, and CYFRA 21-1 in pleural puncture fluid. They found that CEA has the highest diagnostic value with sensitivity of $87.2 \%$ and specificity of $92.3 \%$ (Son et al., 2015). The sensitivity was considerably lower in our data, while specificity was similar $-92.4 \%$.

\section{CONCLUSIONS}

The analysis of our data and that of several authors indicate that:

1. In cases of malignant effusion the level of $\mathrm{Ca}-125$ and CEA are significantly higher in pleural fluid.

2. The relatively high accuracy of Ca-125 and CEA, upon determining them in pleural fluid, allows use of these markers as additional diagnostic criteria for the determination of malignancy; however, neither the Ca-125 and CEA level in serum, nor puncture fluid/serum ratio have considerable diagnostic significance.

\section{ACKNOWLEDGEMENTS}

The authors acknowledge the support by ROCHE Latvija Academy.

\section{REFERENCES}

Bielsa, S., Esquerda, A., Salud, A., Montes, A., Arellano, E., RodríguezPanadero, F., Porcel, J. M. (2009). High levels of tumour markers in pleural fluid correlate with poor survival in patients with adenocarcinomatous or squamous malignant effusions. Eur. J. Intern. Med., 20 (4), 383-386.

Choi, W. I., Qama, D., Lee, M. Y., Kwon, K. Y., (2013). Pleural cancer antigen-125 levels in benign and malignant pleural effusions. Int. J. Tuberc. Lung Dis., 17 (5), 693-697.

Durak-Nalbantic, A., Resic, N., Kulic, M., Pecar, E., Zvizdic, F., Dzubur, A., Dilic, M., Gojak, R., Sokolovic, S., Hodzic, E., Brdjanovic, S. (2013). Serum level of tumour marker carbohydrate antigen-CA125 in heart failure. Med. Arch., 67 (4), 241-244.

Hooper, C., Lee, Y. C., Maskell, N. BTS Pleural Guideline Group (2010). Investigation of a unilateral pleural effusion in adults: British Thoracic Society Pleural Disease Guideline 2010. Thorax, 65, Suppl. 2, ii4-17.

How, S. H., Liam, C. K., Jamalludin, A. R., Chin, S. P., Zal, A. B. (2006). Serum cancer antigen 125 in patients with pleural effusions. Med. J. Malaysia, 61 (5), 558-563.

Kalantri, Y., Naik, G., Joshi, S. P., Jain, A., Phatak, S., Chavan, R,, Hemvani, N, Chitnis, D. S. (2007). Role of cancer antigen-125 from pleural \& ascitic fluid samples in nonmalignant conditions. Indian J. Med. Res., 125 (1), 25-30.

Light, R. W., Macgregor, M. I., Luchsinger, P. C., Ball, W. C. Jr. (1972). Pkeuras effusions: The diagnostic separation of transudates and exudates. Ann. Intern. Med., 77 (4), 507-513.

Lowry, R. (1998-2012). t-Test for Correlated Samples. Available at: http://faculty.vassar.edu/lowry/t_corr_stats.html (accessed 01.08.2015).

Ma, J., Zhao, Y., Wang, Y., Guo, Y., Li, J. (2013). Tumor marker levels in patients aged 85 years and older with chronic heart failure. Eur. J. Intern. Med., 24 (5), 440-443.

Moss, E. L., Hollingwoth, J., Reynolds, T. M., (2005). The role of CA-125 in clinical practice. J. Clin. Pathol., 58, 308-312.

Nicholson, B. D., Shinkins, B., Pathiraja, I., Roberts, N. W., James, T. J., Mallett, S., Perera, R., Primrose, J. N., Mant, D. (2015). Blood CEA levels for detecting recurrent colorectal cancer. Cochrane Database of Systematic Reviews. Available at: http://onlinelibrary.wiley.com/doi/10.1002/ 14651858.CD011134.pub2/full (accessed 01.08.2015); DOI: 10.1002/14651858.CD011134.pub2.

Rodríguez-Panadero, F. (2003). Effusions from malignancy. In: Light, R. W., Lee, Y. C. G. (eds.). Textbook of Pleural Diseases. Arnold Press, London, pp. 297-309.

Preacher, K. J. (2001). Calculation for the chi-square test: An interactive calculation tool for chi-square tests of goodness of fit and independence. Available at: http://quantpsy.org.

Sahn, S. A. (1997). Pleural diseases related to metastatic malignancies. Eur. Respir. J., 10 (8), 1907-1913.

Son, S. M., Han, H. S., An, J. Y., Choe, K. H., Lee, K. M., Lee, K. H., Kim, S. S., Lee, Y. M., Lee, H. C., Song, H. G., Lee, O. J. (2015). Diagnostic performance of CD66c in lung adenocarcinoma-associated malignant pleural effusion: Comparison with CEA, CA 19-9, and CYFRA 21-1. Pathology, 47 (2), 123-129.

Turk, H. M., Pekdemir, H., Buyukberber, S., Sevinc, A., Camci, C., Kocabas, R., Tarakcioglu, M., Buyukberber, N. M. (2003). Serum CA-125 levels in patients with chronic heart failure and accompanying pleural fluid. Tumour Biol., 24 (4), 172-175.

Xu, C. H., Hao, K. K., Yu, L. K., Zhang, X. W. Diagnostic value of soluble receptor-binding cancer antigen expressed on SiSo cells and carcinoembryonic antigen in malignant pleural effusion in patients with lung cancer. (2015). Asia Pac. J. Clin. Oncol., 11 (1), 28-33. 


\section{AUDZĒJA MARḲIERU Ca-125 UN CEA DIAGNOSTISKĀ VĒRTĪBA MALIGNU PLEIRAS ŠḲIDRUMU DIFERENCIĀL- DIAGNOSTIKĀ}

Audzēja marḳieru karbohidrāta antigēna 125 (Ca-125) un karcinoembrionālā antigēna (CEA) līmeņu nozīme ḷaundabīgas un labdabīgas etioloğijas pleiras šḳidruma diferenciāldiagnostikā joprojām tiek pētīta. Šai prospektīvajā pētījumā tika analizēts 121 pacients ar dažādas etioloǵijas šķidrumu pleiras dobumā. Maligni pleiras eksudāti tika konstatēti 55 pacientiem, parapneimoniski pleirīti — 28 pacientiem, kardiālas etiolog̣ijas transudāti -31 pacientam, pankreatogēns eksudāts -1 pacientam, tuberkulozi pleirìti -5 pacientiem. Visiem pacientiem tika noteikti Ca-125 un CEA līmeṇi pleiras punktātā, serumā un aprēkināta to pleiras punktāta/seruma attiecība. Visaugstākā precizitāte ļaundabīgu pleiras eksudātu diagnostikā tika konstatēta Ca-125 un CEA lìmeñiem pleiras punktātā — attiecīgi 75,2\% pie robežlīmeņa $\geq 1452 \mathrm{U} / \mathrm{mL}$ un 76,9\% pie robežlīmeņa $\geq 6.58 \mathrm{ng} / \mathrm{mL}$. Mēs secinājām, ka audzēju marķieru Ca-125 un CEA līmeņa noteikšanai pleiras punktātā ir papildus diagnostiska nozīme ḷaundabīgas un labdabīgas etioloǵijas pleiras škidrumu diferenciāldiagnostikā. 